\title{
PAN AM FLIGHT 103 INVESTIGATION AND LESSONS LEARNED
}

\author{
Sergey Ushynskyi \\ National Aviation University \\ Kiev, Kosmonavta Komarova Ave. 1, 03680 Ukraine
}

E-mail:eduicao@nau.edu.ua

Received 14 May 2009, accepted 11 April 2009

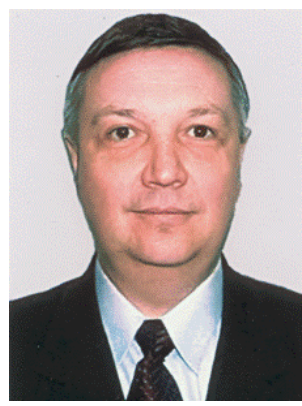

\section{Sergey USHYNSKYI}

Affiliations and functions: ICAO AVSEC auditor, ICAO NATIONAL AVSEC auditor, master of economics and business administration.

Present position: head of AVSEC audit and standardization unit, AVSEC Division, Ukraine International Airlines.

Abstract. On 21 December 1988, one of the most tragic incidents in the history of civil aviation took place. But the lessons of that tragic day and the impact of "Pan Am 103" or "Lockerbie" remain valuable and deserve attention.

Keywords: incident, aviation security, bomb, disruption, lesson.

\section{Introduction}

On 21 December 1988, Air Malta Flight 180 arrived in Frankfurt as scheduled and discharged its passengers and baggage into the Frankfurt International Airport distribution system.

A brown Samsonite suitcase with an Improvised Explosive Device (IED) was entered into the Frankfurt Airport automatic baggage distribution system at a midfield entry point. PAA-103A was not departing until some time later (around 4 hours); the suitcase with the IED was retained in the Frankfurt Airport automatic baggage system until a command was subsequently given to the baggage computer system to discharge all bags of PAA-103A at Gate 46. The brown Samsonite suitcase, together with other suitcases, was driven from Gate 46 to Gate 44 for X-ray.

The baggage (after the X-ray control was completed) was delivered to PAA-103A and placed in the hold of a B-727.

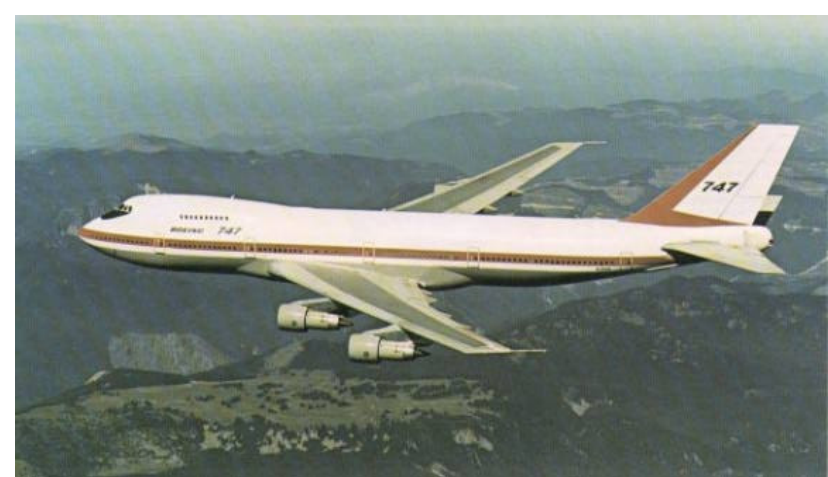

Fig 1. PAN AM Flight 103, December 21, 1988

The fatal journey of flight PAA-103 began from Frankfurt International Airport on the afternoon of 21 December 1988. The bomb inside the suitcase was transferred through the baggage transfer facilities at Heathrow Airport from PAA-103A (B-727) to PAA-103 (B-747). 
The last words received from the Pan Am aircraft on 21 December 1988 were "Clipper 103 requesting oceanic clearance" as co-pilot Raymond Wagner requested clearance to begin the scheduled flight 103 over the Atlantic Ocean to New York.

Soon after that, air traffic controller Alan Topp, who watched Flight PA103 as it crossed Scottish airspace, saw that the aircraft's transponder stopped replying somewhere over Lockerbie. The ATC controller tried again to communicate with Clipper 103, but there was no reply. Not one, but several radar returns on his screen at last altogether disappeared.

A ULD-3 container in the forward cargo hold contained that brown Samsonite suitcase. It was located on the left side of the aircraft, forward of the wing.

A detonated bomb ripped a hole in the side of the container near the left side of the aircraft and a hole in the aircraft skin. The pressure wave met the resistance of the adjacent bags in the container, contents in the forward hold, and other containers. Then it reverberated backward to the opened holes of the container and the skin of the aircraft.

Under influence of the reflective wave, the holes widened. The aircraft skin then opened up and down like a zipper. The forward part of the aircraft separated from the rest of the structure less than 3 seconds after the initial detonation. It swung around to the right and fell away over the right wing. Other parts of the aircraft then began to separate into pieces and, along with its passengers and crew fell to the ground (Fig 2). Eleven citizens of Lockerbie were also killed.

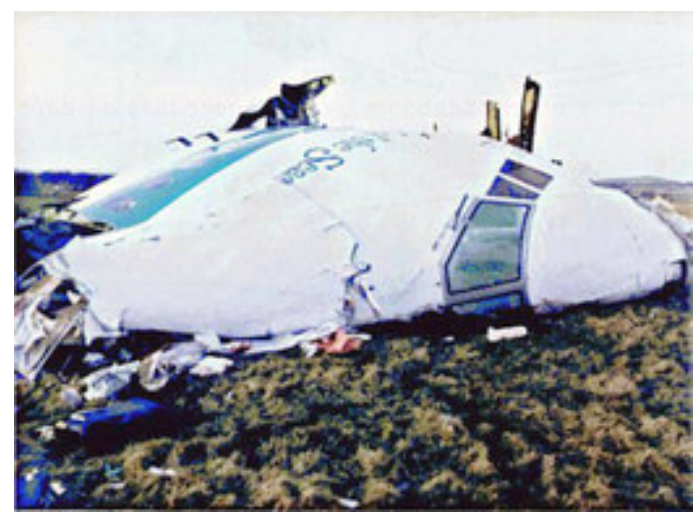

Fig 2. Nose section of Clipper Maid of the Seas

\section{Trail of wreckage}

Distinct north and south trails of wreckage from the aircraft took place, spreading from Lockerbie east towards the coast. An area of 845 square miles was subsequently searched and the instruction to sector commanders was "if it's not growing in the ground, recover it". The aircraft weighed 318 metric tonnes, 107 tonnes of which was aviation fuel. This left 211 tonnes of passengers, crew, cargo, mail, aircraft, and other contents to be recovered (Fig 3).

Some sectors had little habitation and few access roads, making searches very difficult. In some areas, tracks had to be cut through forests to facilitate the search and recovery operation. During the search operation, 18,209 individual items of property were recovered, which included $90 \%$ of the destroyed aircraft.
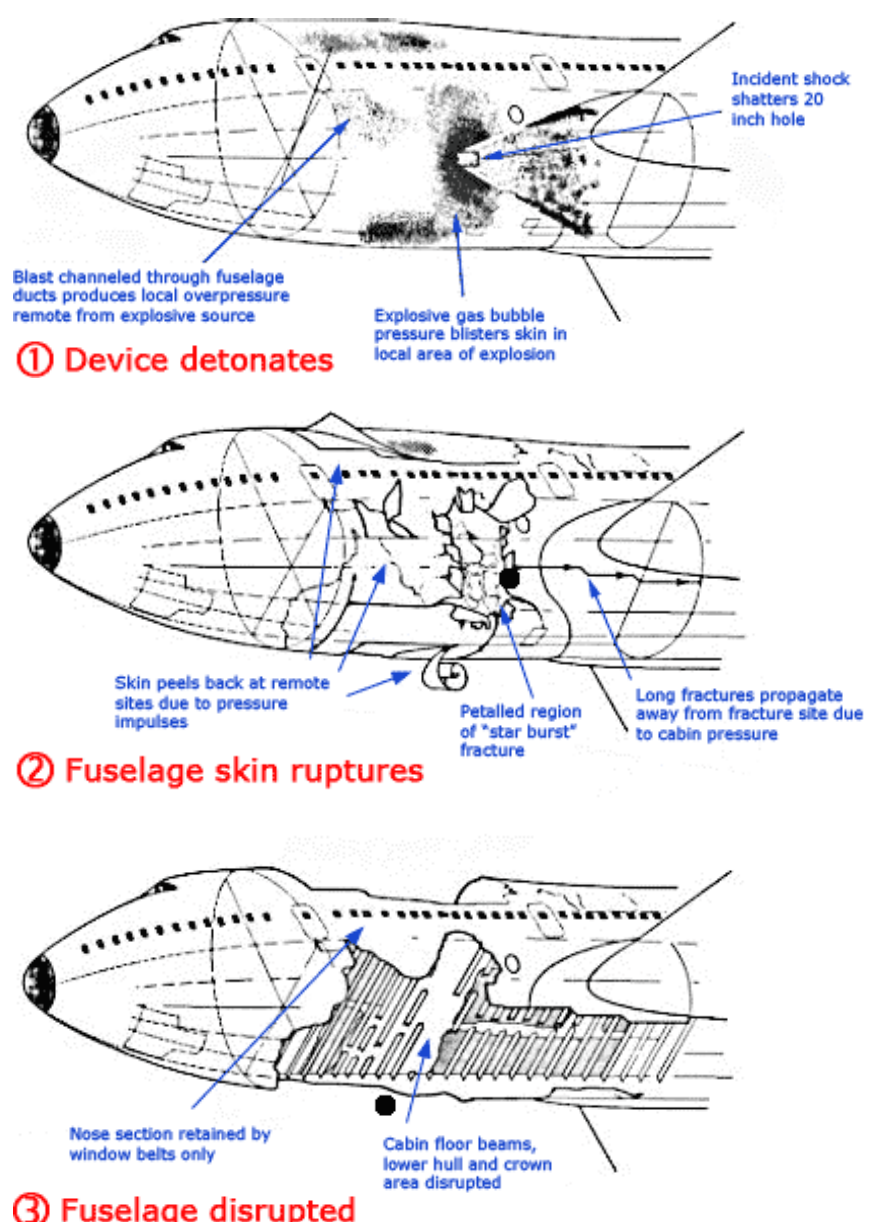

Fig 3. Disruption of fuselage

\section{Detonation of high performance plastic explosive}

The investigation obtained the status of a major murder investigation as soon as forensic examination had identified the presence of chemicals found in Semtex. The cell of the Popular Front for the Liberation of Palestine - General Command that had been operating in Germany prior to the bombing of Pan Am 103 was the focus of the criminal investigation. The German Police arrested members of this cell during Operation Autumn Leaves in October 1988. Weapons and explosives, including an IED within a Toshiba radio cassette recorder (model No R0453D), which was triggered by a basic timing mechanism, were recovered by the German police at this time.

It was learned that this device - a barometric trigger to activate the timer at a certain altitude - was intended to be used by the PFLP-GC against aircraft and in order to avoid a premature explosion.

When scientists found a fragment of a printed circuit board on part of the luggage container from Pan Am 103 into which the explosive device had been loaded, these enquiries took on a greater significance. 
The Royal Armament Research and Development Establishment of the United Kingdom (RARDE) made extensive enquiries. Police also established that the fragment of printed circuit board came from a Toshiba radio cassette recorder. Other debris recovered, including a fragment from the owner's instruction manual, subsequently allowed forensic scientists to identify the model as a Toshiba RTSF16 radio cassette recorder. It was significantly different from the model used by the PFLPGC.

A witness incidentally recovered a fragment of the instruction manual along with other debris near her house in Morpeth, Northumberland. But obviously the significance of this evidence at the time was not known. (Pan... 2008).

\section{The criminal investigation}

The radio cassette recorder fragments were also recovered from clothing damaged by explosives, which, according to the conclusion of forensic scientists, were in close proximity to the IED. The forensic examination of the clothing also produced one of the most important pieces of evidence of this investigation. A fragment of printed circuit board was found in a grey shirt made by Slalom, and the forensic scientists concluded that it had an intimate involvement in the explosion. In their report they stated: "This fragment represents the only recovered piece of modification in the Toshiba radio which would have been necessary to convert it into a delayed action bomb".

The improvised explosive devices recovered by the German police were thereafter examined by forensic scientists, but they did not find any components that matched the fragment of circuit board recovered from the bomb which destroyed Pan Am 103. However, it was evident from the forensic examination and aircraft reconstruction that an explosive device had been placed onboard the aircraft.

Pieces of a blast-damaged suitcase had been recovered (56 pieces of the suitcase were recovered during the search operation (845 square miles), and it was identified as an antique copper 26" Samsonite Silhouette 4,000 hard shell suitcase.

A fragment from a pair of trousers bearing the brand name Yorkie and the number 1705 was also recovered during the search operation.

Although the PFLP-GC remained the main suspects for the bombing, this evidence at that time allowed the investigation to follow definite lines of enquiry. Significant efforts were made worldwide to identify the fragment of circuit board from the IED because of its obvious importance. Enquiries had also revealed that the Yorkie Clothing Company (Malta) manufactured the Yorkie brand of clothing exclusively. Enquiries with the company confirmed that the fragment of trousers recovered from a hillside in south-western Scotland had been manufactured by them. It was also learned that the number 1705 stamped on the trousers was an order number and referred to an order placed with them by a retail outlet known as Mary's House in Sliema, Malta.
Anthony Gauci, proprietor of the family-owned business, told officers that he could recall selling the trousers and other clothing to a Libyan on or about Wednesday, 7 December 1988, 2 weeks before Pan Am Flight 103 was destroyed.

Details of the other clothing purchased by the Libyan which matched the blast damaged clothing recovered at Lockerbie were also given by Gauci (including the grey Slalom shirt mentioned before). He recalled selling an umbrella to this man, and an umbrella of the make described by him was recovered at Lockerbie. Forensic scientists examined it and they discovered that it had been in close proximity to the explosion. Thus the credibility of his evidence was reinforced.

As mentioned before, a Libyan was described by Gauci as the person who purchased the clothing. It was at this time that the first connection between a Libyan citizen or citizens and the bombing of Pan Am 103 was made. He also helped investigators to produce a photofit of the man who attended his shop to purchase the clothing.

The German BKA provided the enquiry with a computer print-out from the baggage handling system at Frankfurt Airport as the focus of the investigation shifted to Malta. It was a record of the bags loaded onto flight Pan Am 103A on 21 December 1988 (the feeder flight for Pan Am 103). This print-out showed that a bag was accepted into the baggage conveyance system at 1307 hours, having been coded for that flight at Station 206. An examination of the coder's work sheet for coding station 206 shows that at 1307 hours on 21 December 1988 the workers were coding bags from flight KM 180 Malta to Frankfurt.

It was established during enquiries that from the Air Malta flight there were no passengers who transferred to Pan Am 103A nor did any of the passengers transfer luggage to this flight. Even more impressive was the fact that no record of unaccompanied luggage transferring to the feeder flight Pan Am 103A from KM 180 on 21 December 1988 was made by Air Malta. The print-out and record sheet therefore confirmed the presence of a suspicious item - an unaccompanied bag transported to London Heathrow from Malta.

It was established by the investigation that Pan Am Flight 103 had been destroyed by an Improvised Explosive Device (IED):

- a Toshiba radio cassette recorder, Model No RTF16 contained the IED inside.

- the presence of chemicals found in Semtex was confirmed by forensic examination.

- the bomb was placed inside a Samsonite suitcase along with clothing purchased in Malta.

- on Wednesday, 7 December 1988 the clothing was purchased by a man who was described as Libyan by Anthony Gauci (a witness).

- this bag was transported on 21 December 1988 from Malta to Frankfurt by flight KM180.

- then it was transferred to Pan Am 103A, which was the interline flight of Pan Am flight 103. 
With the assistance of the FBI and CIA, it was also established in 1990 that the fragment of circuit board from the IED was part of a printed circuit board from an MST-13 timer.

The FBI and CIA recovered MST-13 timers from Togo and Senegal. In February 1988, a Senegalese national was arrested at Dakar Airport together with two members of the Libyan Intelligence Service. An MST-13 timer was recovered at the airport amongst the weapons and explosives. The two Libyans were later released from custody by Senegalese authorities. But any knowledge of the weapons and explosives recovered at the airport were denied by them during the interview, and thus the source of the recovered timers was not confirmed.

MEBO (a Swiss company) commercially produced the MST 13 timers. It was also learned that Swiss Nationals Erwin Meister and Edwin Bollier owned the company. The company regularly did business with Libya and specialized in communications equipment. They (Meister and Bollier) confirmed to investigators that the printed circuit board piece was a part of an MST 13 timer.

In 1985, these particular timers were produced for the Libyan Security Service exclusively.

Bollier also confirmed that:

- in December 1988 he received an order for more of these timers;

- 20 MST 13 timers had been produced and delivered to the Libyans by his company;

- he had helped to train Libyan personnel to use the timers at a training camp in the Sabha Desert in Libya;

- he provided the Libyans with 40 Olympus timers as he could not complete their order. They were returned to him because they were more expensive and inferior to the MST 13 timers;

- Abdelbaset Ali Mohmed Al Megrahi and Badri Hassan were partners in the company ASH, which rented offices from MEBO in Zurich.

Ballier also stated that he thought Abdelbaset Ali Mohmed Al Megrahi was a major in the Libyan Security Service (Fig 4).

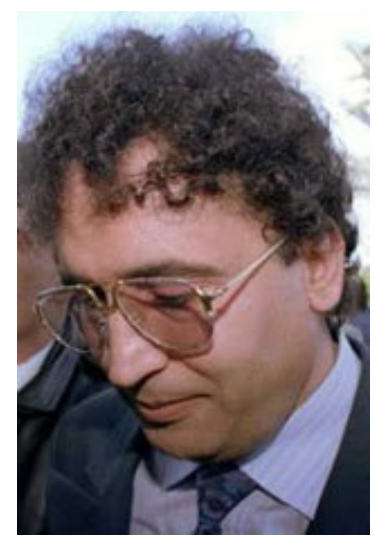

Fig 4. Abdel Basset Ali al-Megrahi

From further investigation and intelligence sources more was learned about Megrahi and his role in the Libyan Security Service. He obtained training as a flight dispatcher (with Libyan Arab Airlines). By 1985 he was head of the Airline Security Section of the Libyan
External Security Organization. In January 1987, he became a director of the Centre for Strategic Studies.

On 15 February 1991, a photograph of Megrahi was shown to Anthony Gaud. He identified Megrahi as resembling the Libyan who purchased clothing in his shop on 7 December 1988 or about that day.

The movements of Megrahi thereafter were subjectted to extensive enquiry. Another purpose was to identify his associates. His movements were established on the basis of the examination of documents: immigration cards, hotel registrations, etc.

Intelligence sources revealed that Ahmed Khalifa Abdusamad was a potential associate of Megrahi.

Documents containing the handwriting of Abdusamad were subjected to forensic examination, and it was established that Abdusamad was probability Megrahi. It was also learned from these documents that Abdusamad stayed at the Malta Holiday Inn on 20-21 December 1988 and left Malta for Tripoli on 21 December 1988.

It was revealed by enquiries at the Holiday Inn that at 7.11 on the morning of 21 December 1988 Abdusamad made a telephone call from his room to telephone No 414570 (local), which was connected to a flat rented by Al Amin Khalifa Fhimah in Malta.

It was then established that Fhimah was the station manager for Libyan Arab Airlines at Luqa Airport in Malta. In 1988, he left this position and set up a tourist company called Medtours with premises in Mosta, Malta. Scottish and Maltese police visited these premises on 22 April 1991 and found a 1988 diary and a security pass for Luqa Airport belonging to Fhimah.

\section{5. "Take tags from the Maltese Airline"}

Several references related to Megrahi were found when the writings in the diary were translated. On 15 December 1988, Fhimah made what was for the enquiry the most valuable entry in his diary: "Take tags from the Maltese Airline". The word tags were underlined twice. He wrote in the notes section of the diary: "Bring the tags from the airport".

Because of this evidence, Fhimah became the suspect. A closer examination of his movements revealed that on 20 December 1988 he travelled from Tripoli to Malta on the same flight together with Ahmed Khalifa Abdusamad.

At the same time, the Central Intelligence Agency disclosed that Abdulmajid Abdul Razkaz Abdulsalam Giaka (Majid), a Libyan intelligence officer, had defected to the United States. Libyan Arab Airlines employed him as an assistant manager at Luqa Airport. In August 1988, he was recruited by the Central Intelligence Agency.

According to his statements, he had worked with Megrahi and Fhimah at Luqa Airport. Abdulmajid had also confirmed to investigators that Megrahi held a senior post in the Libyan Intelligence Service.

It had originally been intended to use Majid as an intelligence source to help develop the criminal investigation.

Majid, when debriefed, provided information about: 
- seeing a high performance explosive in Fhimah's desk at Luqa Airport between 1986 and 1988;

- seeing Fhimah and Megrahi at Luqa Airport in December 1988 with two other Libyans in possession of a brown hard-shell suitcase similar in description to the IED suitcase;

- the identification of key players and the structure of the Libyan Intelligence Service;

- the association/position of Megrahi and Fhimah within the Libyan Intelligence Service and the relationship between them.

United States Authorities decided that Majid could be used as a witness against Megrahi and Fhimah because the information he gave was of great value to the investigation.

United States Authorities placed Majid and his family in the Witness Protection Program.

\section{The arrest and trial of the two accused}

On 13 November 1991, after a review of all the evidence, a petition warrant was subsequently granted at Dumfries Sheriff Court for the arrest of Abdelbaset Ali Mohmed AI Megrahi and Al Amin Khalife Fhimah on charges of murder, conspiracy to murder, and a contravention of the Aviation Security Act of 1982. trial.

But Libya refused to hand over the two accused for

An agreement was however reached for a trial to take place on a neutral territory under the laws of Scotland, following extensive international negotiations supported by UN Sanctions.

The High Court of Justiciary (Proceedings in the Netherlands) (United Nations) Order 1998, supported by agreements of the governments of the United Kingdom and the Netherlands, provided the legal framework for the trial to take place in Holland. The legislation in fact created a little part of Scotland in the Netherlands.

A former American Air Force Base at Kamp Van Zeist near Soesterberg was identified as the site for the Scottish Court.

The buildings on the site, which was approximately 100 acres in size, were identified as appropriate for refurbishment and redevelopment for use as a court, a prison, a cafeteria, accommodation blocks, etc.

Megrahi and Fhimah were formally arrested on 5 April 1999. There was an expectation, however, that the process to extradite them from Holland to Little Scotland for trial would take several months.

An identification parade was held at Kamp Van Zeist for Megrahi on 13 April. When Anthony Gauci viewed the parade, he identified Megrahi as the person who had purchased the clothing from his shop.

UN resolutions also required Libya to fully cooperate with the police investigation into the bombing of Pan Am 103, apart from handing over the accused. A number of people, including a government minister and other high ranking officials were interviewed after the submission of a formal letter of request. The director of the Libyan Passport Agency and the administrative director of the Libyan Intelligence Service were among those interviewed. It was established that the Passport Agency issued a passport in the name of Ahmed Kalifah Abdusumad on 15 August 1987 in response to a letter from the Libyan Intelligence Service. During an interview, the administrative director of the Libyan Intelligence Service confirmed that the Intelligence Service had requested the issue of the passport.

This was incriminating evidence against Megrahi. The coded passport in the name of Ahmed Kalifah Abdusumad was later recovered from the defence team.

Thus the suspicion that Megrahi was Abdusumad was confirmed by this evidence. It was also confirmed that he used this passport on 20 December 1988 to travel to Malta together with Fhimah and that the passport was used several times in 1987, only once in 1988 and not used after 21 December 1988.

On 3 May 2000 the trial of Megrahi and Fhimah began. The evidence of the former Libyan Intelligence Officer, Abdulmajid, who defected to the United States, was a significant part of the case against Fhimah. As evidence in the trial, cables (redacted) from Majid's CIA handlers were used. It should be mentioned that the CIA had never previously made documents or witnesses available to a foreign court. But this time the CIA even made available evidence of payments to Majid.

In any way, Fhimah was acquitted of the charges against him and returned to Tripoli on 31 January 2001. (Presentation ... 1990).

According to international media, Scotland's government 20/08/09 released Megrahi from a life sentence for the 1988 bombing of Pan Am Flight 103 over Lockerbie in Scotland because he has terminal prostate cancer. Libyan leader Muammar Gaddafi hugged the convicted Lockerbie bomber and promised more cooperation with_Britain in gratitude for his release, while London and Washington condemned his "hero's welcome" home.

Gaddafi's comments drew a flat denial from Britain that Megrahi's release was in any way linked to business deals with Libya, which has Africa's largest proven oil reserves. Britain said all responsibility for his release rested with Scotland, which runs its own judicial affairs (Opinion...2002).

\section{Lessons learned}

\section{Global-level lessons}

Lessons to be learned from the Pan Am 103 or "Lockerbie" terrorist attack, which happened 20 years ago, remain valuable today.

In January 1989, the USA and UK requested a special session of the International Civil Aviation Organization (ICAO) Council "to improve international aviation security procedures" in response to the destruction of Pan Am 103. A special session of the ICAO council was held on 15-16 February 1989. During this significant international meeting, ways of responding to acts of unlawful interference against civil aviation were discussed.

This attempt to strengthen aviation security can be considered the most important effect of those tragic 
events on further improvement and future development of harmonized and standardized aviation security measures.

At this session, an eight-point plan suggested by the United Kingdom and supported by the United States as the basis for improvements in aviation security throughout the entire world was adopted.

ICAO organization and powers were strengthened after this conference. This resulted in the improvement of aviation security regulations, training and quality control. Lockerbie also caused many states to enhance civil aviation security measures.

It should be mentioned that legislation addressing compensation for victims of air disasters was one of the most important changes in civil aviation as a result of Pan Am 103. Revisions to the Montreal Convention replaced the Warsaw Convention (by November 2003).

At the same time, "Lockerbie" was the mechanism for the formation and implementation of the ICAO Convention on Marking Plastic Explosives (1991). The convention requires states producing such explosives to mark them at the time of manufacture to enhance their ability to be detected by available mechanical detectors or canine.

"Lockerbie" has also elaborated the US policy regarding states that sponsor terrorism. This policy, economic sanctions and isolationism, brought Libya to admit responsibility for the "Lockerbie" attacks and agree to pay compensation to the families of victims.

Another lesson is that the families of "Lockerbie" victims should be thanked for their activity to establish policy and ensuing legislation providing support from airlines and states for aircraft accidents survivors and families of victims. The Aviation Disaster Family Assistance Act and the Foreign Air Carrier Family Support Act were enacted in 1996 and 1997 correspondingly.

The artful concealment used by Lockerbie terrorists made the detection of explosives very difficult for screeners. Explosive detection systems and explosive trace detection were designed after "Lockerbie" as an attempt to develop equipment for the reliable detection of explosives and explosive devices. It became possible due to increased funding of research and development of this detection equipment.

Cargo security was amended by new standards for screening and practices based on the "known" and "unknown" shipper concepts.

Realization of new procedures and physical methods of control regarding electronic and electrical equipment such as radios and computers were achieved. Use of passenger questioning was reiterated in further addressing this issue.

Implementation of one of the most important standards for screening of checked and transfer baggage both at check-in and between flights to achieve $100 \%$ hold baggage screening became reality, and automated, in-line, and multi-level baggage screening system technologies commenced operating.

The sabotage in "Lockerbie" resulted in more effective usage of so called bingo cards (base of manual reconciliation procedures), which evolved to become the automated baggage reconciliation systems working now in many airports across the world.

Another lesson of Lockerbie yet to be implemented by civil aviation is contained in the recommendations of the aircraft accident report:

"The following safety recommendations were made during the course of the investigation:

That airworthiness authorities and aircraft manufacturers undertake a systematic study with a view to identifying measures that might mitigate

4.5 the effects of explosive devices and improve the tolerance of aircraft structures and systems to explosive damage" (Charles 1990).

As a result, much research was done to improve the structure of aircraft and harden the cargo hold and containers against the consequences of IED blasts. Efforts in this area continue.

The aviation security community initiated higher standards of access to restricted areas of airports, i.e. security control of people and vehicles entering these areas. Background checks of aviation personnel, particularly security employees, were a significant part of these efforts.

"Lockerbie" also should never be forgotten as an example of an insider threat. The head of security of an airline (Abdel al-Megrahi) was found guilty of having perpetrated the attack. This challenge from inside the system is another lesson and one of the greatest threats to aviation security in the future, as well as self-satisfaction: Pan American Airlines was found guilty of "wilful misconduct by failing to prevent a bomb from being smuggled aboard the flight".

With time passing by, we observe how the tactics of terrorist are changing, especially after the events of 9/11, subsequent "anti-terrorist" wars, and the resistance thus generated. Aviation security countermeasures continue to re-act; they and their enhancements remain reactive (not active) to any act of unlawful interference. This lesson is probably the most disquieting of all "Lockerbie" lessons.

Risk assessment and comprehensive evaluation of threats to civil aviation based on detailed intelligence made by those responsible may be one of the ways to prevent terrorist plans, which continue to be developed on the basis of holes in our aviation security systems, persistently searched by malefactors. But are current and new security countermeasures, such as background checks, staff screening, $100 \%$ hold baggage screening, enhanced cockpit doors and sky marshals as effective as expected? Are there any doubts whether there will be a next? Actually it is just a question of when.

Still it should not be forgotten, that if PA 103 flight departed from Heathrow on time and exploded over the Atlantic, little important evidence would have been found to teach us the lessons of "Lockerbie" (Anderes 2008).

\section{AVSEC QC \& QA lessons}

Most of the deficiencies in the AVSEC system that resulted in the Pan Am 103 tragedy could have been 
detected during an audit or prevented by proper AVSEC organization.

\subsection{FAA'S requirement to physically search all unaccompanied baggage}

The FAA regulation that required that all US air carriers physically search all unaccompanied baggage from high-threat airports was specifically designed to detect and prevent bombs from getting on US air carriers. This FAA regulation was the outgrowth of the 23 June 1985 Air India Flight 182 tragedy that killed 329 persons over the Atlantic Ocean. The Air India tragedy resulted from an unaccompanied bag put on board by a Sikh terrorist in Vancouver, British Colombia, Canada.

This US Government security requirement to physically search all unaccompanied baggage delayed departing aircraft whenever baggage not associated with a passenger was on board. The baggage then had to be located and removed from the aircraft and physically searched before it could be re-boarded without the passenger. This situation occurred most often from passengers and baggage connecting from other air carriers. Pan Am officials, seeing an opportunity to avoid such delays, decided to examine all interline baggage prior to placing it on their aircraft at Frankfurt and London. When Pan Am began X-raying all interline baggage they discontinued their baggage/passenger reconciliation for interline baggage but continued to conduct baggage/passenger reconciliation for all originating passengers at Heathrow and Frankfurt. This substitution of X-ray examination for baggage/passenger reconciliation violated the FAA regulation requiring that all unaccompanied baggage be physically searched. A US Federal Court subsequently determined that this action by Pan Am was in contravention of the US Government (FAA) regulation. In making this finding, the US federal court found Pan Am guilty of "wilful misconduct" and in violation of US laws implementing the international Warsaw Convention.

Given the FAA's security requirement to physically search all unaccompanied bags, with its implicit requirement to conduct a full baggage/passenger reconciliation, opportunities were missed at both Frankfurt and Heathrow international airports to catch the suitcase containing the Toshiba radio with the concealed IED. The most egregious error, however, was by Pan Am and Alert Management employees at Frankfurt International Airport. The Alert Security Company (a subsidiary of Pan Am) employee who was operating the Pan Am X-ray had begun his X-ray experience in late October 1988. He had received approximately 3 days of supervised training before being allowed to operate the X-ray unit unsupervised. In the intervening 1.5 months he had Xrayed a total of approximately 350 bags, a minimum amount of experience by any standard.

Pan Am abandoned the FAA requirement to conduct a baggage/passenger reconciliation for interline passengers at Heathrow Airport in early 1988, and at Frankfurt in September/October 1988 when they began to X-ray all interline baggage.
Audit procedures or processes such as interviews and observations could have been used to determine that Pan Am was not in compliance with the FAA's full baggage/passenger reconciliation requirement.

\subsection{PAN AM's misrepresentation of security staffing levels}

Testimony in a US federal court in 1992 revealed that Pan Am's subsidiary security organization, Alert Management, misrepresented the level of their security staffing. This testimony revealed that as the FAA special agent conducted his audit, Alert Management moved security personnel from one point to another, creating the impression that their staffing was greater than it actually was.

From an audit standpoint, this subterfuge could have been detected during the audit if it had been properly planned and conducted.

\subsection{PAN AM's X-Raying of interline baggage at Frankfurt and Heathrow PAN AM's failure to conduct a full baggage/passenger reconciliation}

Pan Am's Alert Management had begun X-raying of interline baggage at Frankfurt and Heathrow airports in early 1988 to X-ray all interline transfer checked baggage at London Heathrow International Airport, and in the September/October timeframe to do the same at Frankfurt International Airport. Pan Am purchased two X-ray units specifically for this purpose from a leading US supplier. At the time, Alert Management officials took this action to X-ray its interline baggage at these two airports where Pan Am was required by the US Federal Aviation Administration to physically search any unaccompanied bags. In order for Pan Am to know that it had unaccompanied baggage on its aircraft, the airline, as with all US air carriers operating from high-threat international airports, had to conduct a full baggage/passenger reconciliation.

The FAA special agent believed that something was amiss with the integrity of Pan Am's security at Frankfurt but could not or did not specifically identify the problem. He did make a note that Pan Am's security was being held together by sheer luck but did not identify the specific weaknesses that were bothering him. Actually, this was not a proper audit and the FAA special agent should have done more.

\subsection{FAA special agent's failure to complete October audit report}

In October 1988, just 2 months before the PAA-103 tragedy, an FAA security special agent conducted a security audit of Pan Am's Frankfurt Airport operations. He intended to complete it and have it typed but with the demands of other audits and associated travel it was still on his desk unprinted on the date of the PAA-103 tragedy, i.e., 21 December 1988. 
Without a doubt, timelier processing of the audit report could have better identified Pan Am's security irregularities at Frankfurt.

\subsection{No passenger transfer message (PTM) for PAA-103 suitcase}

Had Pan Am conducted the required baggage/ passenger reconciliation at either Frankfurt or at Heathrow airports they would have discovered the brown Samsonite suitcase containing the Toshiba radio-cassette player with the IED. They then would have had to determine which passenger was associated with the bag. And further checking would have revealed that no passenger transfer message (PTM) had been received from Air Malta at Frankfurt that would have identified a passenger associated with the bag containing the bomb. Having determined this, Pan Am would have been required to turn the bag over to the German authorities, which would have had to isolate the bag in the Frankfurt Airport because of its suspicious nature. Added to these contributing events was the fact that Pan Am had abandoned the US government's requirement to physically search all unaccompanied baggage.

The absence of a PTM from Air Malta for the suitcase containing the IED was discovered during security audits at those airports.

\subsection{PAN AM's ground security coordinators}

Pan Am, like all US airlines, was required by FAA regulations to have a person trained as a ground security coordinator. The functions of this position were to ensure that all required security measures for each Pan Am flight were correctly carried out before the flight could depart. Testimony in a US federal court in 1992 revealed that neither ground security coordinator for PAA-103 at Frankfurt and Heathrow was properly trained, and as a consequence, they were not properly discharging their duties on 21 December 1988.

An audit could have easily detected these deficiencies by examining training records and job descriptions.

\subsection{PAN AM's Alert Management security training}

Subsequent to the PAA-103 tragedy, it was determined that Alert Management's training of its personnel was inadequate, and the vetting of its personnel raised questions about the appropriateness of some of its employees.

An audit could also have detected these deficiencies by examining related documents, regulations, training records, and job descriptions.

\subsection{Neuss barometric bomb and Helsinki threat}

The first of these events occurred in October 1988 in Neuss, Germany, when the German police interdicted a Palestinian Front for the Liberation of Palestine General Command (PFLP-GC) terrorist cell. The German police confiscated two radio/hi-fi tuners and a Toshiba Bombeat Radio from a PFLP-GC terrorist cell vehicle during their interdiction activities. Examination of the Toshiba radio by German explosive ordnance disposal (EOD) experts revealed that the radio contained a sophisticated improvised explosive device (IED) with a triggering/ timing mechanism that included a digital timer that was activated by a barometer switch. It was obvious to these EOD experts that the device was intended for use against aviation. As a result of this conclusion, the information about this IED was widely distributed through intelligence networks to other nations, including the USA.

NOTE: Subsequent handling of one of the two hi-fi tuners during an EOD examination about a month following the destruction of PAA-103 resulted in the detonation of an IED, and the EOD expert doing the examination was killed.

The Pan Am Alert Security organization at Frankfurt had failed to take proper action to distribute and train their personnel about the warning from Helsinki, Finland issued by the US government (FAA). In early December 1988, a caller to the US Embassy in Helsinki had warned that Middle Eastern terrorists intended to place a bomb on board a US airplane out of Frankfurt sometime in the next 2 weeks. That warning of a threat was issued to all US air carriers by the FAA headquarters in Washington, D.C., U.S.A. but never received the proper distribution by the Pan Am Alert Security organization at the Frankfurt International Airport. So, as noted above, the Pan Am Alert Security X-ray operator was not aware of the need to specifically look for radios in the articles that he was X-raying, nor was he on any heightened state of alert because of the Helsinki threat (for which the 2-week period had expired a few days before the Pan Am tragedy).

Examination by attorneys for the relatives of the victims of PAA-103 revealed in a US federal court in 1992 that the Pan Am Alert Management security organization at Frankfurt had not properly distributed the warnings that they had received from German secret services about the Neuss Toshiba radio IED that had been found in October 1988. As a consequence, the Alert Management baggage X-ray operator at Frankfurt Gate 44 had not been informed, either formally or informally, to be on the alert (no pun intended) for radios in baggage.

The Pan Am security subsidiary, Alert Management, had not properly distributed nor informed its employees about the discovery of the bomb with a barometric trigger in the Toshiba radio in Neuss, Germany in October. Neither had Alert Management properly distributed the information to its employees about the Helsinki threat issued by the US government. These types of failures could be identified in audits. 


\subsection{Stolen baggage tags}

Evidence presented in the Scottish court showed that a terrorist operating from the Luqa International Airport and allegedly assisted by others concealed an IED in a Toshiba Bombeat Radio Cassette Player. He then caused the IED to be placed into a brown Samsonite suitcase, along with an odd assortment of clothes and an umbrella purchased at Mary's Shop in Malta. The terrorist, or an accomplice, had stolen blank baggage tags from Air Malta and on December 21 surreptitiously placed the brown Samsonite suitcase into the Air Malta baggage system at Luqa International Airport. The stolen bag tag from Air Malta was marked to route the brown Samsonite suitcase on Air Malta Flight 180 to Frankfurt then to be interlined to PAA Flight 103 (PAA-103 A at Frankfurt) with a final destination of John F. Kennedy International Airport in New York, U.S.A.

The convicted terrorist, or his accomplice(s), stole blank Air Malta baggage tags to use to surreptitiously introduce the brown Samsonite suitcase containing the radio (that contained the bomb) into the Air Malta baggage system.

A proper AVSEC audit could have determined the integrity of the airline's baggage tag protection system.

In September 1989 the President's Commission on Aviation Security and Terrorism (PCAST) stated:

National will and the moral courage to exercise it are the ultimate means of defeating terrorism. The Commission recommends a more vigorous policy that not only pursues and punishes terrorists, but also makes state sponsors of terrorism pay a price for their actions.

We must make every effort to ensure that the lessons learned from Pan Am 103 are transferred to the next generation of aviation security personnel and that they do their best to prevent what we now call an "act of unlawful interference".

\section{Conclusions}

This article systemizes the official version of information regarding Lockerbie accident, which may be of interest to AVSEC personnel, especially to those involved into AVSEC QA and QQ, AVSEC training etc.

It also gives a good example of AVSEC investigation to be made after an act of unlawful interference (AUI). Though, the process of AVSEC accident/ AUI investigation is required by International and National regulatory acts of ICAO member States and is a part of AVSEC personnel duties, this activity is usually out of AVSEC specialists attention and has yet not got a detailed description in relative manuals and instructions.

This material also gives an example of system approach to AVSEC QC and QA activities/ AVSEC auditor responsibilities in making conclusions, which may influence present and future state of security in relative civil aviation environment.

\section{References}

Anderes, V. 2008. Global Impact of Pan Am 103: 20 years after Lockerbie. ASI.

Case study PAN AM Flight-103 December 21, 1988. 1989. Jordan Regional Centre For Aviation Security \& Safety.

Charles, M. M. 1990. Report on the accident to Boeing 747-121, N739PA at Lockerbie, Dumfriesshire, Scotland on 21 December 1988.

OPINION OF THE COURT delivered by the Lord Justice General in appeal against conviction of Abdelbaset Ali Mohmed Al Megrahi (Appellant) against Her Majesty's Advocate (Respondent): Appeal No C104/01 14. 2002. Available from Internet: <http://www.bintulu.org/news/ 2009/08/22/libya-britaian-gaddafi-hugslockerbie-bomber.php $>$.

Pan Am Flight 103 [online] 2008. In Wikipedia, the free encyclopedia. Available from Internet: $<$ www.wikipedia.org $>$.

Presentation of Detective Chief Superintendent Tom McCulloch. 1990. In Lockerbie Investigation for AVSEC World.

\section{PAN AM 103 SKRYDIS: TYRINĖJIMAS IR IŠMOKTA PAMOKA}

S. Ushynskyi

S antrauka

1988 m. gruodžio 21 d. ịvyko vienas tragiškiausių incidentų civilinès aviacijos istorijoje. Tačiau šios tragiškos dienos pamokos ir Pan Am 103 arba kitaip Lockerbie katastrofa turi išliekamają vertę.

Reikšminiai žodžiai: incidentas, aviacinis saugumas, bomba, irimas, pamoka. 